Annals of International Medical and Dental Research

E-ISSN: 2395-2822 | P-ISSN: 2395-2814

Vol-8, Issue-2 | March-April 2022

DOI: 10.53339/aimdr.2022.8.2.26

Page no- 200-208 | Section- Research Article (Medicine)

\title{
Differences between Men and Women in Terms of Clinical Features of ST-Segment Elevation Acute Myocardial Infarction
}

\author{
Musammat Sufia Akther1*, Mirza Abul Kalam Mohiudden², Shamshad Khan', Ratul Sakaobe \\ Shefa ${ }^{4}$, Ayesha Mubashshira Labiba ${ }^{5}$
}

$\begin{array}{lrrr}{ }^{1} \text { Assistant } & \text { Professor, } & \text { Department } & \text { of } \\ \text { Cardiology, } & \text { National } & \text { Institute } & \text { of }\end{array}$ Cardiovascular Disease, Dhaka, Bangladesh. Email: drmusammatsufia@.gmail.com,

Orcid ID: 0000-0002-4691-1323

2Senior Consultant, Department of Caddiac Surgery, United Hospital Ltd, Dhaka, Bangladesh. Email: drmirzakalam@gmail.com, Orcid ID: 0000-0001-5043-6548

3Blackpool Jeachiay Hospital, NHS Foundation Trust, Dhaka, Bangladesh.

Email: drmirzakalam@gmail.com,

Orcid ID: 0000-0001-5988-6238

4IBN SINA Medical College Hospital Dhaka, Bangladesh. Email: drratulmirza@gmail.com, Orcid ID: 0000-0003-3112-4471.

5IBN SINA Medical College Hospital Dhaka, Bangladesh. Email: 5197aysha@gmail.com, Orcid ID: 0000-0003-1617-3718

${ }^{*}$ Corresponding author

Received: 16 December 2021

Revised: 20 January 2022

Accepted: 29 January 2022

Published: 18 February 2022

\begin{abstract}
Background: Several research have investigated further into differences in clinical characteristics of acute myocardial infarction between men and women (AMI). Prospective studies, on the other hand, are few, and sex-related variations in AMI symptoms are unknown. We studied at the variations in clinical characteristics of ST-segment elevation AMI between men and women. Material \& Methods: We evaluated at 151 patients with ST-segment elevation AMI who were hospitalized within 24 hours of symptom onset (70 women and 81 males). Within 48 hours of hospitalization, all patients were interviewed by many of the same cardiologist. Results: Women exhibited higher rates of hypertension (70 vs 56 percent, $\mathrm{p}=0.010$ ), diabetes mellitus ( 36 vs $26 \%, \mathrm{p}=0.047$ ), and hyperlipidemia (51 vs $38 \%, \mathrm{p}=0.019)$ than males (72 vs 62 years, $\mathrm{p} 0.001$ ). Non-specific symptoms (45 vs $34 \%$, p=0.033), non-chest discomfort (pain in the mouth, throat, neck, shoulder, arm, hand, and back), moderate pain ( 20 vs $7 \%$, p0.001), and nausea ( 49 vs 36 percent, $p=0.013$ ) were all more common in women than in males. The severity of coronary artery lesions was equal in both sexes on coronary angiography. Women had a considerably greater in-hospital death rate than males (6.6 vs. $1.4 \%$, $\mathrm{p}=0.003)$. Conclusions: Women and men with AMI have different clinical profiles and presentations. AMI symptoms are less common in women than in males.
\end{abstract}

Keywords:- Gender, Myocardial infarction, Prognosis.

\section{INTRODUCTION}

Many investigations examining sex differences in the short and long-term outcomes of an acute myocardial infarction (AMI) have reported that mortality is higher in women than in men. $[1,2,3,4,5,6,7,8,9,10]$ The cause for women's lower results is unknown. Women's higher mortality rates may be explained in part by the fact that they were older than males and had higher incidence of adverse prognostic variables in previous studies. Several studies, however, remained to reveal a mortality disadvantage for women after controlling for these characteristics. $[2,3,5,8]$ The fact that these women received less aggressive AMI therapy than males may explain why mortality remains higher following risk adjustment. $[2,3,8,11]$ Adjusting for baseline differences between men and women, however, provided 
Annals of International Medical and Dental Research

E-ISSN: 2395-2822 | P-ISSN: 2395-2814

Vol-8, Issue-2 | March-April 2022

DOI: 10.53339/aimdr.2022.8.2.26

Page no- 200-208 | Section- Research Article (Medicine)

conflicting results. Several studies have indicated that sex is an independent risk factor for increased mortality following an AMI, 1,4$]$ whereas others have not. $[6,7,12]$ Another factor that may contribute to women's greater mortality rates is their later entrance to the hospital. $[13,14]$ Women with AMI usually arrive at the hospital later than males, implying distinct behavioral reactions. When experiencing AMI symptoms, women are thought to be less likely than males to assume they are suffering a heart attack.[15] Several studies have found that women's AMI symptoms are different or less prevalent than men's.[14,16,17] Non-chest pain, nausea or vomiting (or both), and shortness of breath are more common in women. $[14,17,18,19,20]$ These atypical symptoms may make it difficult for not only women with AMI,but also bystanders and health-care providers to correctly interpret the situation and take appropriate action. An important limitation of previous studies examining sex related differences in symptom presentation among patients with AMI was their retrospective design. Patients were interviewed by many different physicians, without the use of a standardized interview form. The results of interviews were thus subject to bias. We prospectively studied a series of men and women who were admitted to the coronary care unit of our Medical Center. In this pilot study, the same cardiologist interviewed all patients within 48 $\mathrm{h}$ after admission to minimize interviewrelated bias.

\section{MATERIAL AND METHODS}

From January 2011 through December 2011, 151 consecutive patients with ST-segment elevation AMI were admitted to our coronary care unit within $24 \mathrm{~h}$ after symptom onset. All patients gave informed consent. Patients were also asked whether AMI was associated with any of the following symptoms:cold sweating, nausea, vomiting, or shortness of breath. Coronary Angiography Coronary angiography was performed immediately after admission in 425 patients $(93 \%)$. The perfusion status of the infarct-related artery was assessed according to the criteria of the Thrombolysis in Myocardial Infarction (TIMI) study.[21] The recanalization method was left to the discretion of the patients' physicians. The final TIMI flow grade was assessed on the basis of final angiograms obtained on admission. Stenosis was considered clinically significant if there was a narrowing of the luminal diameter by $\geq 75 \%$ in any projection.Cardiac-Enzyme Measurements Blood samples were obtained on admission, at 3-h intervals during the first $24 \mathrm{~h}$ after admission, at 6-h intervals for the next 2 days, and then daily until discharge.Statistical Analysis Data are expressed as mean \pm SD. The statistical significance of differences between men and women was evaluated with the use of unpaired t-tests. Differences in prevalence were assessed with the use of chi-square tests. A $p$ value of $<0.05$ was considered to indicate statistical significance. Analyses were conducted with SPSS-PC software,version 24.0 (SPSS, Chicago, IL, USA).

\section{RESULTS}

Baseline Characteristics Of the 457 patients studied, 351 (77\%) were men and 106 (23\%) were women. The baseline characteristics of the subjects are shown according to sex in [Table 1]. Overall, the women were older than the men and were more likely to have a lower body-mass index, diabetes mellitus, 
Annals of International Medical and Dental Research E-ISSN: 2395-2822 | P-ISSN: 2395-2814

Vol-8, Issue-2 | March-April 2022

DOI: 10.53339/aimdr.2022.8.2.26

Page no- 200-208 | Section- Research Article (Medicine)

hyperlipidemia, and hypertension. Women were less likely to have a history of smoking. Hemodynamic variables on admission and the rates of previous infarction, percutaneous coronary intervention, and coronary-artery bypass graft surgery did AMI was diagnosed on the basis of typical chest pain lasting $\geq 30$ min, ST-segment elevation of $\geq 2 \mathrm{~mm}$ in at least 2 contiguous precordial leads or ST-segment elevation of $\geq 1 \mathrm{~mm}$ in at least 2 inferior leads (II, III, or aVF), and a typical increase in serum creatine kinase to more than twice the upper limit of normal. We studied 457 patients (351 men and 106 women) in whom a detailed clinical history was obtained within $48 \mathrm{~h}$ after admission. Their mean ( \pm SD) age was $65 \pm 12$ years (range, 31 to 93 years). Fiftythree patients were excluded from the study because of cardiogenic shock $(n=25)$, dementia $(n=8)$, early death $(n=2)$, or other conditions precluding the assessment of pain within $48 \mathrm{~h}$ after admission $(n=18)$. The peak creatine kinase level was significantly lower in women than in men. During hospitalization (mean, 14 days), 12 patients $(2.6 \%)$ died: 7 women (5 of cardiac rupture and 2 of heart failure) and 5 men (3 of heart failure, 1 of infection, and 1 of stroke). In-hospital mortality was significantly higher in women than in men. The 5 women who died of cardiac rupture during hospitalization were elderly (mean age, 85 years) and had high rates of hypertension and anterior myocardial infarction. In addition, 2 patients did not receive and 1 patient did not respond to reperfusion therapy [Table 4].

Table 1: Baseline Characteristics of Patients with ST-Segment Elevation AMI According to Sex

\begin{tabular}{|l|l|l|l|}
\hline & Women (n=70) & Men (n=81) & p value \\
\hline Age (years) & $72 \pm 12$ & $62 \pm 11$ & $<0.001$ \\
\hline Height $(\mathrm{cm})$ & $151 \pm 6$ & $165 \pm 6$ & $<0.001$ \\
\hline Weight $(\mathrm{kg})$ & $52 \pm 9$ & $66 \pm 11$ & $<0.001$ \\
\hline Body mass index (kg/m2) & $23.1 \pm 3.8$ & $24.4 \pm 3.2$ & 0.044 \\
\hline Time from symptom onset to admission (h) & $4.6 \pm 4.5$ & $3.7 \pm 4.0$ & 0.07 \\
\hline Heart rate on admission & $82 \pm 21$ & $77 \pm 22$ & 0.18 \\
\hline Systolic blood pressure on admission $(\mathrm{mmHg})$ & $129 \pm 38$ & $137 \pm 32$ & 0.20 \\
\hline Killip $\geq 2$ on admission & $16(15 \%)$ & $34(10 \%)$ & 0.12 \\
\hline Symptom onset $\leq 6 \mathrm{~h}$ & $83(78 \%)$ & $294(84 \%)$ & 0.20 \\
\hline Prior myocardial infarction & $13(12 \%)$ & $32(9 \%)$ & 0.34 \\
\hline Prior coronary artery bypass surgery & $3(3 \%)$ & $5(1 \%)$ & 0.33 \\
\hline Pre-infarction angina & $52(49 \%)$ & $141(40 \%)$ & 0.11 \\
\hline Risk factors & & & \\
\hline Diabetes mellitus & $38(36 \%)$ & $91(26 \%)$ & 0.047 \\
\hline Hyperlipidemia & $54(51 \%)$ & $134(38 \%)$ & 0.019 \\
\hline Hypertension & $74(70 \%)$ & $196(56 \%)$ & 0.010 \\
\hline Smoking & $28(26 \%)$ & $246(70 \%)$ & $<0.001$ \\
\hline Medication before AMI & & \\
\hline
\end{tabular}

Copyright: (The author(s), published in Annals of International Medical and Dental Research, Vol-8, Issue-2. This is an open access article under the Attribution-Non Commercial 2.0 Generic (CC BY-NC 2.0) license. (https://creativecommons.org/licenses/by-nc/2.0/) 
Annals of International Medical and Dental Research E-ISSN: 2395-2822 | P-ISSN: 2395-2814

Vol-8, Issue-2 | March-April 2022

DOI: 10.53339/aimdr.2022.8.2.26

Page no- 200-208 | Section- Research Article (Medicine)

\begin{tabular}{|l|l|l|l|}
\hline Aspirin & $20(19 \%)$ & $41(12 \%)$ & 0.06 \\
\hline Blocker & $8(8 \%)$ & $20(6 \%)$ & 0.49 \\
\hline ACE inhibitor & $7(7 \%)$ & $22(6 \%)$ & 0.90 \\
\hline Ca channel blocker & $34(32 \%)$ & $75(21 \%)$ & 0.023 \\
\hline HMG CoA & $20(19 \%)$ & $33(9 \%)$ & 0.008 \\
\hline Peak creatine kinase (IU/L) & $2,355 \pm 1,729$ & $3,161 \pm 2,553$ & 0.003 \\
\hline In-hospital death & $7(6.6 \%)$ & $5(1.4 \%)$ & 0.003 \\
\hline
\end{tabular}

Table 2: Incidence and Nature of Symptoms Associated With ST-Segment Elevation AMI According to Sex

\begin{tabular}{|c|c|c|c|}
\hline & Women $(n=70))$ & Men $(n=81)$ & p value \\
\hline \multicolumn{4}{|l|}{ Type of chest pain } \\
\hline Squeezed feeling & $33(32 \%)$ & $122(35 \%)$ & 0.49 \\
\hline Compressed or pressed down feeling & $18(17 \%)$ & $85(24 \%)$ & 0.12 \\
\hline Burning or searing feeling & $3(3 \%)$ & $22(6 \%)$ & 0.17 \\
\hline Burst open or split feeling & $4(4 \%)$ & $3(1 \%)$ & 0.032 \\
\hline Others & $48(45 \%)$ & $119(34 \%)$ & 0.033 \\
\hline \multicolumn{4}{|l|}{ Site of pain } \\
\hline Jaw & $10(9 \%)$ & $9(3 \%)$ & 0.002 \\
\hline Throat and neck & $14(13 \%)$ & $19(5 \%)$ & 0.00 \\
\hline Anterior chest & $94(89 \%)$ & $310(88 \%)$ & 0.92 \\
\hline Left shoulder & $13(12 \%)$ & $19(5 \%)$ & 0.015 \\
\hline Left arm, forearm, and/or hand & $12(11 \%)$ & $18(5 \%)$ & 0.024 \\
\hline Right shoulder & $10(9 \%)$ & $13(4 \%)$ & 0.018 \\
\hline Right arm, forearm, and/or hand & $8(8 \%)$ & $10(3 \%)$ & 0.029 \\
\hline Epigastric region & $8(8 \%)$ & $33(9 \%)$ & 0.56 \\
\hline Epigastric region & $8(8 \%)$ & $33(9 \%)$ & 0.56 \\
\hline Back & $25(24 \%)$ & $41(12 \%)$ & 0.002 \\
\hline Severity of pain & & & $<0.001$ \\
\hline Very severe & $10(9 \%)$ & $32(9 \%)$ & \\
\hline Severe & $40(38 \%)$ & $183(52 \%)$ & \\
\hline Moderate & $35(33 \%)$ & $113(32 \%)$ & \\
\hline Mild & $21(20 \%)$ & $23(7 \%)$ & \\
\hline \multicolumn{4}{|l|}{ Concomitant symptoms } \\
\hline Cold sweating & $67(63 \%)$ & $272(78 \%)$ & 0.003 \\
\hline Nausea & $52(49 \%)$ & $125(36 \%)$ & 0.013 \\
\hline Vomiting & $24(25 \%)$ & $54(15 \%)$ & 0.08 \\
\hline Shortness of breath & $66(62 \%)$ & $183(52 \%)$ & 0.07 \\
\hline
\end{tabular}


Annals of International Medical and Dental Research E-ISSN: 2395-2822 | P-ISSN: 2395-2814

Vol-8, Issue-2 | March-April 2022

DOI: 10.53339/aimdr.2022.8.2.26

Page no- 200-208 | Section- Research Article (Medicine)

Table 3: Angiographic Findings in Patients with ST-Segment Elevation AMI According to Sex

\begin{tabular}{|l|l|l|l|}
\hline & Women (n=70) & Men (n=81) & p value \\
\hline Emergency coronary angiography & $96(91 \%)$ & $329(94 \%)$ & 0.26 \\
\hline Number of diseased vessels* & & & 0.90 \\
\hline 1 & $60 / 96(63 \%)$ & $214 / 329(65 \%)$ & \\
\hline 2 & $26 / 96(27 \%)$ & $83 / 329(25 \%)$ & \\
\hline 3 & $10 / 96(10 \%)$ & $32 / 329(10 \%)$ & 0.47 \\
\hline Infarct-related artery* & & & \\
\hline LAD & $52 / 96(54 \%)$ & $149 / 329(45 \%)$ & \\
\hline RCA & $33 / 96(35 \%)$ & $138 / 329(42 \%)$ & \\
\hline LCX & $8 / 96(8 \%)$ & $35 / 329(11 \%)$ & \\
\hline LMT & $2 / 96(2 \%)$ & $4 / 329(1 \%)$ & 0.35 \\
\hline Bypass graft & $1 / 96$ & $(1 \%) 1 / 329(0.3 \%)$ & 0.12 \\
\hline Undefined & 0 & $2 / 329(0.6 \%)$ & 0.14 \\
\hline Reperfusion therapy & $88(83 \%)$ & $304(87 \%)$ & 0.77 \\
\hline PCI & $78(74 \%)$ & $230(66 \%)$ & 0.18 \\
\hline Stent & $60(57 \%)$ & $170(48 \%)$ & 0.50 \\
\hline CABG & $3(3 \%)$ & $12(3 \%)$ & 0.75 \\
\hline TIMI flow grade 0 at initial CAG* & $48 / 96(50 \%)$ & $141 / 329(43 \%)$ & 0.97 \\
\hline Final TIMI flow grade $\geq 2^{*}$ & $90 / 96(94 \%)$ & $314 / 329(95 \%)$ & 0.65 \\
\hline Final TIMI flow grade 3* & $85 / 96(89 \%)$ & $295 / 329(90 \%)$ & 0.28 \\
\hline PCI during hospitalization & $88(83 \%)$ & $292(83 \%)$ & $220(63 \%)$ \\
\hline Stenting during hospitalization & $69(65 \%)$ & $19(5 \%)$ & \\
\hline CABG during hospitalization & $3(3 \%)$ & & \\
\hline
\end{tabular}

Table 4: Clinical Characteristics of Patients Who Died of Cardiac Rupture During Hospitalization

\begin{tabular}{|l|l|l|l|l|l|l|l|l|l|}
\hline $\begin{array}{l}\text { Age } \\
\text { years) }\end{array}$ & Sex & $\begin{array}{l}\text { Time to } \\
\text { Admission } \\
\mathbf{( h )}\end{array}$ & $\begin{array}{l}\text { BMI } \\
\mathbf{( k g / m 2})\end{array}$ & DM & Hypertension & $\begin{array}{l}\text { Infarct } \\
\text { location }\end{array}$ & $\begin{array}{l}\text { Reperfusion } \\
\text { therapy }\end{array}$ & $\begin{array}{l}\text { Final TIMI } \\
\text { flow grade }\end{array}$ & $\begin{array}{l}\text { Time to } \\
\text { death }\end{array}$ \\
\hline 77 & F & 6.5 & 23 & No & Yes & Anterior & Stent & 2 & \\
\hline 80 & F & 4.5 & 25 & Yes & Yes & Anterior & Stent & 3 & 5 days \\
\hline 86 & F & 7.0 & 22 & Yes & Yes & Inferior & Stent & 0 & $41 \mathrm{~h}$ \\
\hline 87 & F & 16.0 & 21 & No & No & Anterior & No & - & 7 days \\
\hline 93 & F & 8.5 & 17 & No & Yes & Anterior & No & - & $40 \mathrm{~h}$ \\
\hline
\end{tabular}

\section{DISCUSSION}

Our studies show that women with AMI are older than males with AMI and are more likely to have cardiac risk factors (except smoking) as well as less frequent AMI symptoms such nonspecific symptoms, non-chest pain (pain in the jaw, neck, arm, or back), nausea, vomiting, and shortness

breath. $[1,2,3,4,5,6,7,8,9,10,11,12,13,14,16,17,18,19,20]$ There was 
Annals of International Medical and Dental Research

E-ISSN: 2395-2822 | P-ISSN: 2395-2814

Vol-8, Issue-2 | March-April 2022

DOI: 10.53339/aimdr.2022.8.2.26

Page no- 200-208 | Section- Research Article (Medicine)

no difference in the amount of fundamental coronary atherosclerosis between men and women. Percutaneous coronary interventions were conducted on the majority of the women $(74 \%)$, much as they were on the males. The baseline and postprocedural TIMI flow grades in women were similar to those in men.However, the in-hospital mortality rate was significantly higher in women than in men. These biological differences between men and women might explain how women's AMI outcomes are much worse than. Pre-AMI, a larger number of women than men were taking anti-platelet medications such aspirin and HMG CoA reductase inhibitors, which are used to prevent cardiovascular disease. Women with AMI have been observed to experience increased non-chest pain, nausea, vomiting, and shortness of breath.[17,18,19,20] Due to the fact that our findings corroborate this conclusion, the frequency of these symptoms was typically greater in our study than in prior studies, important because it suggests that our patients were questioned more thoroughly. It's unknown why ladies suffered so many unusual symptoms. Diabetes mellitus and advanced age, according to Culic et al, are linked to atypical AMI signs and symptoms [22]. Many of the women in this research were elderly and had diabetes, which might explain the increased incidence of unusual symptoms. Less common AMI symptoms may be wrongly assigned to musculoskeletal, gastrointestinal, or neurologic diseases. Furthermore, we discovered that women were more likely than males to experience moderate discomfort at the outset of AMI, extending the time it took to be admitted to the hospital. The degree of acute chest discomfort was already determined to be unrelated to an increased risk of death in people suffering from the condition. [23] Women with AMI are more prone to develop nonspecific symptoms, such as non-chest discomfort, moderate pain, nausea, vomiting, and shortness of breath, which patients and physicians must be aware of. Thrombolytic treatment, percutaneous transluminal coronary angioplasty, and coronary artery bypass grafting both are less common among women than in men. $[2,3,8,11,24]$ Moreover, so the majority of our patients received coronary bypass surgery, the effects of treatment biases on mortality are thought to be low. In consideration of coronary angiographic findings, the incidence of underlying coronary atherosclerosis, as well as the baseline and postprocedural TIMI flow grades, were similar in men and women, reflecting previous findings. $[1,6,25,26]$ Cardiogenic shock is more common in women than in males, according to previous studies. $[1,27]$ We didn't include individuals with cardiogenic shock since we couldn't get an extensive medical history. Considering this, women's in-hospital mortality rates were nearly 5 consistently higher than men's. The primary cause of inhospital mortality among women in this study was cardiac rupture. Associated with subsequent, female sex, and a lower BMI were all reported to be risk factors for myocardial rupture during AMI by Yip et al.[28] Early successful direct percuta-avoidance of heart rupture following AMI was described. Our findings are consistent with those of Yip et al. In the current research, however, only 5 students experience cardiac rupture. To determine the clinical features of heart rupture, further study in large study groups is recommended. 
Annals of International Medical and Dental Research

E-ISSN: 2395-2822 | P-ISSN: 2395-2814

Vol-8, Issue-2 | March-April 2022

DOI: 10.53339/aimdr.2022.8.2.26

Page no- 200-208 | Section- Research Article (Medicine)

\section{Limitation of the study}

A very small number of patients with STsegment elevation AMI were included in this research, which was conducted at a single center and included a complete medical history. To avoid biases, all respondents were questioned prospectively by the same cardiologist to define the types and severity of symptoms caused by AMI. As a consequence, we consider our findings are less distorted than those of past research in which the medical histories of patients were examined by several different cardiologists.

\section{CONCLUSIONS}

The reality that women had a worse result from AMI might be due to a number of

\section{REFERENCES}

1. Vakili BA, Kaplan RC, Brown DL. Sex-based differences in early mortality of patients undergoing primary angioplasty for first acute myocardial infarction. Circulation. 2001;104(25):3034-8. doi: 10.1161/hc5001.101060.

2. Kudenchuk PJ, Maynard C, Martin JS, Wirkus M, Weaver WD. Comparison of presentation, treatment, and outcome of acute myocardial infarction in men versus women (the Myocardial Infarction Triage and Intervention Registry). Am J Cardiol. 1996;78(1):9-14. doi: 10.1016/s0002-9149(96)00218-4.

3. Chandra NC, Ziegelstein RC, Rogers WJ, Tiefenbrunn AJ, Gore JM, French WJ, et al. Observations of the treatment of women in the United States with myocardial infarction: a report from the National Registry of Myocardial InfarctionI. Arch Intern Med. 1998;158(9):981-8. doi: 10.1001/archinte.158.9.981.

4. Marso SP, Gowda M, O'Keefe JH, Coen MM, McCallister BD, Giorgi LV, et al. Improving inhospital mortality in the setting of an increasing risk profile among patients undergoing catheter-based variables. Men and women with AMI had different baseline biologic parameters (age, BMI, concomitant illness), as well as varied symptoms and behavioral reactions during the outset of AMI, according to our findings.

\section{Recommendation}

Further prospective studies involving larger numbers of patients are required to further assess the effects of these differences on clinical outcomes. Women with AMI should receive earlier, more aggressive treatment. We believe that the role of health-care professionals in educating patients to promptly recognize and respond to possible cardiac symptoms is essential for improved survival after AMI, especially in women.

reperfusion for an acute myocardial infarction without cardiogenic shock. J Invasive Cardiol. 2003;15(12):711-6.

5. Wilkinson P, Laji K, Ranjadayalan K, Parsons L, Timmis AD. Acute myocardial infarction in women: survival analysis in first six months. BMJ. 1994;309(6954):566-569. doi:10.1136/bmj.309.6954.566

6. Tamis-Holland JE, Palazzo A, Stebbins AL, Slater JN, Boland J, Ellis SG, et al; GUSTO II-B Angioplasty Substudy Investigators. Benefits of direct angioplasty for women and men with acute myocardial infarction: results of the Global Use of Strategies to Open Occluded Arteries in Acute Coronary Syndromes Angioplasty (GUSTO II-B) Angioplasty Substudy. Am Heart J. 2004;147(1):1339. doi: 10.1016/j.ahj.2003.06.002.

7. Lansky AJ, Pietras C, Costa RA, Tsuchiya Y, Brodie BR, Cox DA, et al. Gender differences in outcomes after primary angioplasty versus primary stenting with and without abciximab for acute myocardial infarction: results of the Controlled Abciximab and Device Investigation to Lower Late Angioplasty Complications (CADILLAC) trial. Circulation. 
Annals of International Medical and Dental Research E-ISSN: 2395-2822 | P-ISSN: 2395-2814

Vol-8, Issue-2 | March-April 2022

DOI: 10.53339/aimdr.2022.8.2.26

Page no- 200-208 | Section- Research Article (Medicine)

2005;111(13):1611-8.

10.1161/01.CIR.0000160362.55803.40.

8. Kostis JB, Wilson AC, O'Dowd K, Gregory P, Chelton S, Cosgrove NM, et al. Sex differences in the management and long-term outcome of acute myocardial infarction: A statewide study: MIDAS Study Group: Myocardial Infarction Data Acquisition System. Circulation 1994; 90: 1715- 1730.

9. Oe K, Shimizu M, Ino H, Yamaguchi $M$, Terai $H$, Hayashi K, Kiyama M, Sakata K, Hayashi T, Inoue M, Kaneda T, Mabuchi H. Effects of gender on the number of diseased vessels and clinical outcome in Japanese patients with acute coronary syndrome. Circ J. 2002;66(5):435-40. doi: 10.1253/circj.66.435.

10. Sakurai K, Watanabe J, Iwabuchi K, Koseki Y, Konno Y, Fukuchi M, Komaru T, Shinozaki T, Miura M, Sakuma M, Kagaya Y, Kitaoka S, Shirato K. Comparison of the efficacy of reperfusion therapies for early mortality from acute myocardial infarction in Japan: registry of Miyagi Study Group for AMI (MsAMI). Circ J. 2003;67(3):209-14. doi: 10.1253/circj.67.209.

11. Yarzebski J, Col N, Pagley P, Savageau J, Gore J, Goldberg R. Gender differences and factors associated with the receipt of thrombolytic therapy in patients with acute myocardial infarction: a community-wide perspective. Am Heart J. 1996;131(1):43-50. doi: 10.1016/s0002-8703(96)900496.

12. Kosuge M, Kimura $\mathrm{K}$, Kojima $\mathrm{S}$, Sakamoto $\mathrm{T}$, Ishihara M, Asada Y, et al; Japanese Acute Coronary Syndrome Study (JACSS) Investigators. Beneficial effect of preinfarction angina on in-hospital outcome is preserved in elderly patients undergoing coronary intervention for anterior acute myocardial infarction. Circ J. 2005;69(6):630-5. doi: 10.1253/circj.69.630.

13. Meischke H, Eisenberg MS, Larsen MP. Prehospital delay interval for patients who use emergency medical services: the effect of heart-related medical conditions and demographic variables. Ann Emerg Med. 1993;22(10):1597-601. doi: 10.1016/s01960644(05)81267-3.

14. Meischke H, Larsen MP, Eisenberg MS. Gender differences in reported symptoms for acute myocardial infarction: impact on prehospital delay time interval. Am J Emerg Med. 1998;16(4):363-6. doi: 10.1016/s0735-6757(98)90128-0.
15. Meischke H, Eisenberg MS, Schaeffer SM, Damon SK, Larsen MP, Henwood DK. Utilization of emergency medical services for symptoms of acute myocardial infarction. Heart Lung. 1995;24(1):11-8. doi: 10.1016/s0147-9563(05)80090-1.

16. McSweeney JC, Crane PB. Challenging the rules: women's prodromal and acute symptoms of myocardial infarction. Res Nurs Health. 2000;23(2):135-46. doi: 10.1002/(sici)1098240x(200004)23:2<135::aid-nur6>3.0.co;2-1.

17. Patel H, Rosengren A, Ekman I. Symptoms in acute coronary syndromes: does sex make a difference? Am Heart J. 2004;148(1):27-33. doi: 10.1016/j.ahj.2004.03.005.

18. Goldberg RJ, O'Donnell C, Yarzebski J, Bigelow C, Savageau J, Gore JM. Sex differences in symptom presentation associated with acute myocardial infarction: a population-based perspective. Am Heart J. 1998;136(2):189-95. doi: 10.1053/hj.1998.v136.88874.

19. Herlitz J, Bång A, Karlson BW, Hartford M. Is there a gender difference in aetiology of chest pain and symptoms associated with acute myocardial infarction? Eur J Emerg Med. 1999;6(4):311-5. doi: 10.1097/00063110-199912000-00007.

20. Goldberg R, Goff D, Cooper L, Luepker R, Zapka J, Bittner $\mathrm{V}$, et al. Age and sex differences in presentation of symptoms among patients with acute coronary disease: the REACT Trial. Rapid Early Action for Coronary Treatment. Coron Artery Dis. 2000;11(5):399-407. doi: 10.1097/00019501200007000-00004.

21. TIMI Study Group. The Thrombolysis in Myocardial Infarction (TIMI) trial. Phase I findings. N Engl J Med. 1985;312(14):932-6. doi: 10.1056/NEJM198504043121437.

22. Culić V, Eterović D, Mirić D, Silić N. Symptom presentation of acute myocardial infarction: influence of sex, age, and risk factors. Am Heart J. 2002;144(6):1012-7. doi: 10.1067/mhj.2002.125625.

23. Herlitz J, Bång $\mathrm{A}$, Isaksson $\mathrm{L}$, Karlsson $\mathrm{T}$. Ambulance despatchers' estimation of intensity of pain and presence of associated symptoms in relation to outcome in patients who call for an ambulance because of acute chest pain. Eur Heart J. 1995;16(12):1789-94.

doi: 10.1093/oxfordjournals.eurheartj.a060829. 
Annals of International Medical and Dental Research

E-ISSN: 2395-2822 | P-ISSN: 2395-2814

Vol-8, Issue-2 | March-April 2022

DOI: 10.53339/aimdr.2022.8.2.26

Page no- 200-208 | Section- Research Article (Medicine)

24. Kinoshita N, Imai K, Kinjo K, Naka M. Longitudinal study of acute myocardial infarction in the southeast Osaka district from 1988 to 2002. Circ J. 2005;69(10):1170-5. doi: 10.1253/circj.69.1170.

25. DeGeare VS, Grines CL. Debate: Should the elderly receive thrombolytic therapy, or primary angioplasty, for acute myocardial infarction? The case for primary angioplasty. Curr Control Trials Cardiovasc Med. 2000;1(3):146-149. doi:10.1186/cvm-1-3-146

26. Mehilli J, Ndrepepa G, Kastrati A, Nekolla SG, Markwardt C, Bollwein $\mathrm{H}$, et al. Gender and myocardial salvage after reperfusion treatment in acute myocardial infarction. J Am Coll Cardiol. 2005;45(6):828-31. doi: 10.1016/j.jacc.2004.11.054.
27. Fiebach NH, Viscoli CM, Horwitz RI. Differences between women and men in survival after myocardial infarction. Biology or methodology? JAMA. 1990;263(8):1092-6.

28. Yip HK, Wu CJ, Chang HW, Wang CP, Cheng CI, Chua S, Chen MC. Cardiac rupture complicating acute myocardial infarction in the direct percutaneous coronary intervention reperfusion era. Chest. 2003;124(2):565-71. doi: 10.1378/chest.124.2.565.

Source of Support: Nil, Conflict of Interest: None declared 